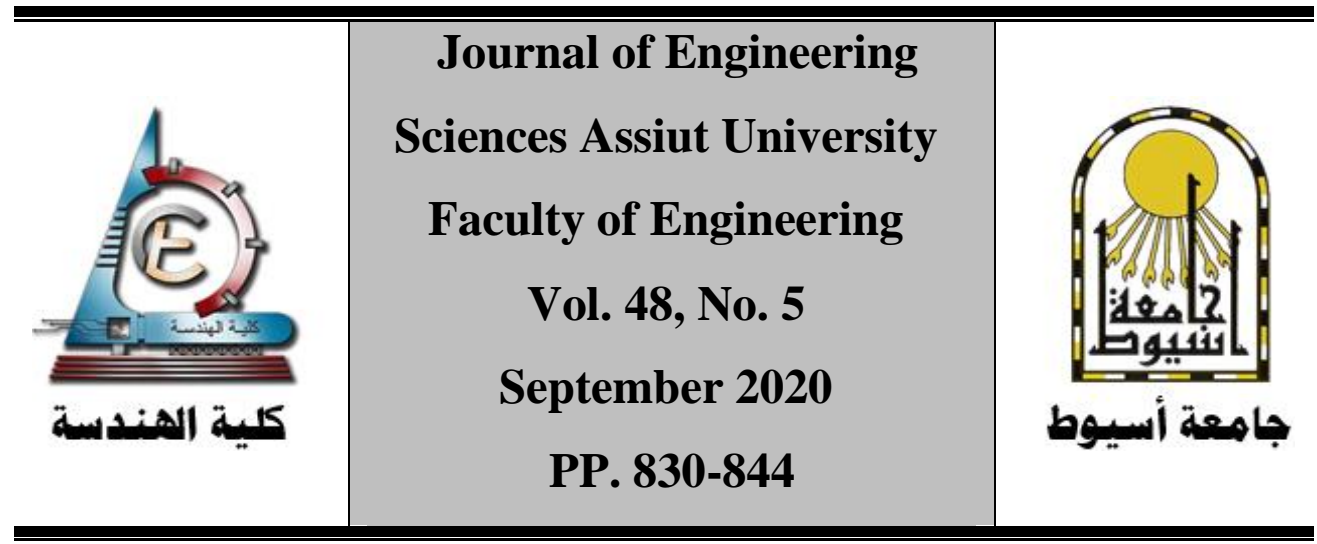

\title{
STABILITY OF GEOGRID REINFORCED EMBANKMENT ON SOFT CLAY
}

\author{
Moamen E. Abd El Raouf*1 \\ ${ }^{1}$ Civil Engineering Department, Faculty of Engineering, Al- Azhar university, Qena, \\ Egypt.
}

Received 19 April 2020; Revised 2 June 2020; Accepted 2 June 2020

\begin{abstract}
The reinforcement by geotextiles or geogrids helps to improve the embankment stability and guarantee more uniform settlement. The factors effect on the stability of the reinforced embankment on soft clay, in terms of slope stability and sliding resistance has been studied using a finite element program (GEO5 program). In this paper, the effect of geogrid Spacing, the height of the first geogrid layer, unit weight of embankment fill, and the angle of internal friction was studied. The numerical model results indicated that the optimum spacing between the geogrid layers is $0.5 \mathrm{~m}$. Increasing the angle of internal friction for the embankment fill causes to increase the factors of safety. Increasing the density of the embankment fill causes to decrease the factors of safety. Also, it was recommended to install the first geogrid layer between the embankment base and underlying soft clay layer without any vertical distance.
\end{abstract}

Keywords: Reinforced Embankment, Geogrid, Soft clay, Lateral sliding, Stability of slope.

\section{Introduction}

Reinforcement of soil can be divided into three categories: (a) reinforcement of a steep slope embankment, (b) reinforcing the backfill soil like mechanically 
stabilized earth wall, (c) reinforcing the foundation soil. The reinforcing unit may be made from geotextile, geogrid, and steel strips. The embankments which are founded on soft clay subject to many problems like settlement, overturning, sliding and shear failure. These problems have a dangerous effect on the safety of the existing embankments. Geosynthetics like polymer grids and Geotextile are used as a reinforcing material. Due to increasing traffic recently, many of road and railways embankments had been constructed on soft clay soil. As shown in figure (1) The reinforcement by geotextiles or geogrids helps to increase the stability against the overall failure of embankment and foundation soil. Also, increase the embankment stability against sliding failure along reinforcing material surface and guarantee more uniform settlement [1]. Reinforced embankment over soft clay can be divided into two categories [2]:

a) Reinforcement to control internal and external stability without controlling settlement (see figure 2).

b) Reinforcement to control both stability and settlement of embankment (see figure 3 ).

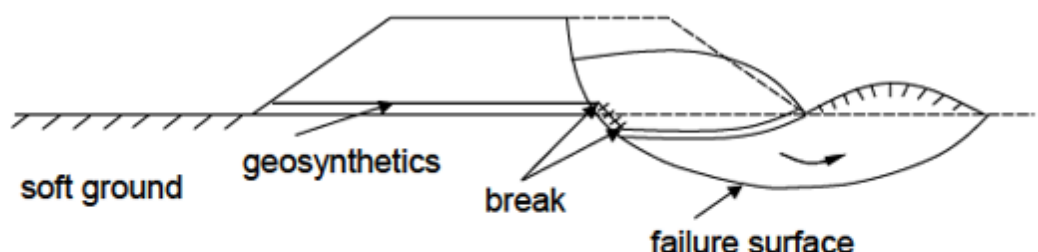

failure surface
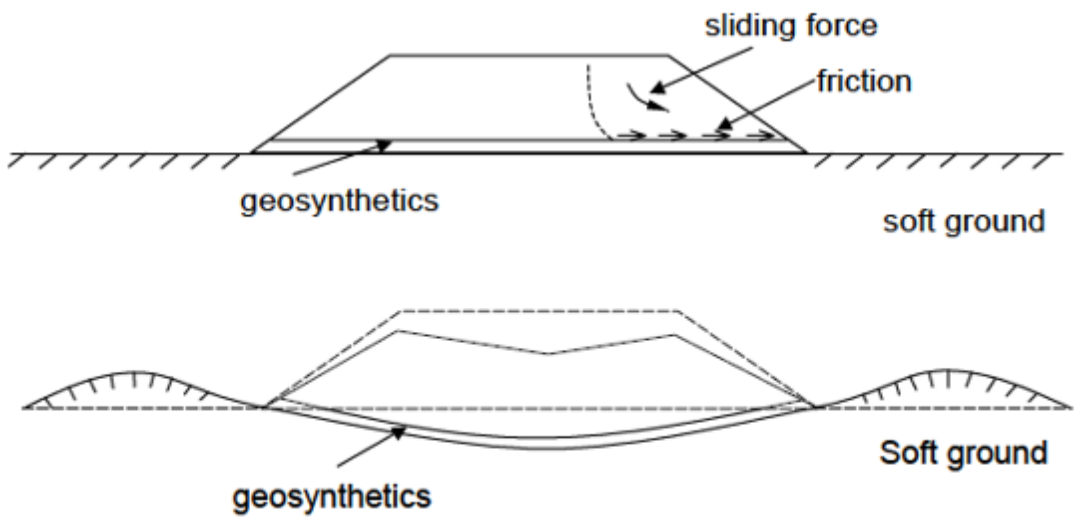

Fig. 1: Effect of Geosynthetics on the stability of embankment on soft soil (after the International Geosynthetics Society). 


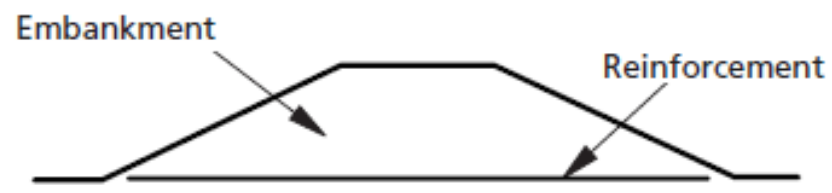

Soft clay foundation

a) Basal reinforcement beneath embankment

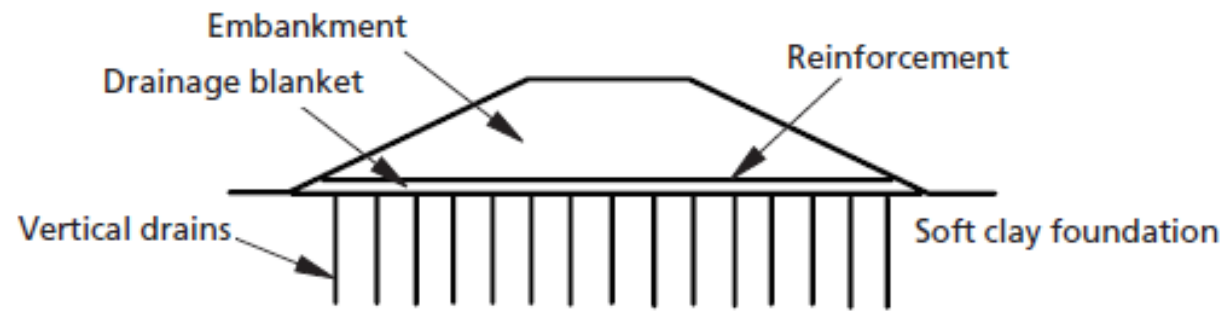

b) Basal reinforcement with vertical drains

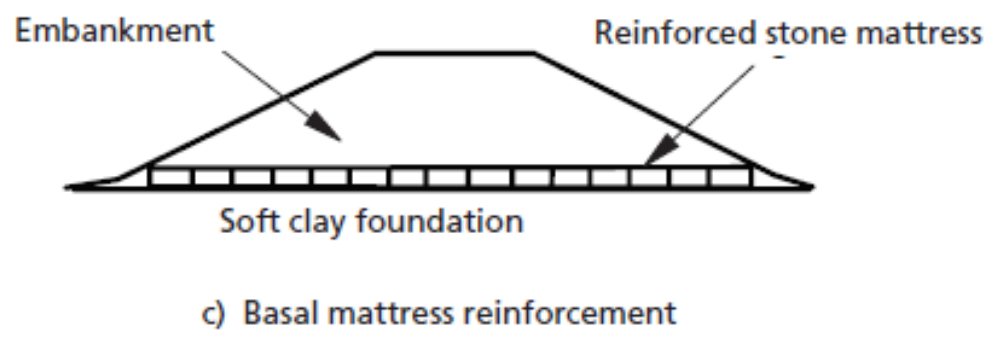

Fig. 2: Control only stability of embankment using reinforcement (after BS 8006-1,2010)

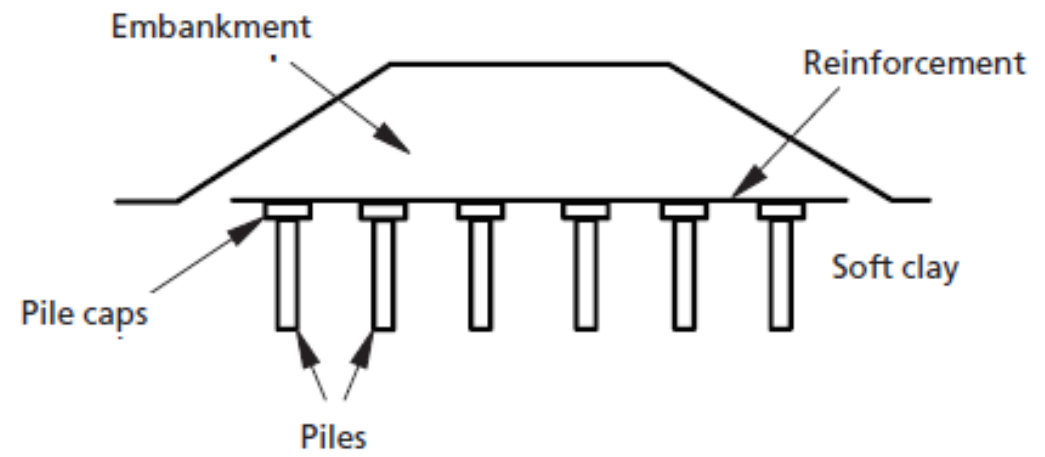

Piled embankment with basal reinforcement

Fig. 3: Control both stability and settlement of embankment using reinforcement (after BS 8006-1,2010) 
Various factors effect on the internal and external stability of the reinforced embankment on soft clay. In this search, the stability of the reinforced embankment on soft clay was studied. This can be achieved by studying the various values of the parameters affect the factors of safety of the reinforced embankment to set the maximum and minimum value of these factors. These parameters include the effect of geogrid spacing, the height of the first geogrid layer, unit weight of embankment fill, and the angle of internal friction. A GEO5 program was used in this analysis to evaluate the influence of changing of varying factors values on the values the safety factors.

\section{The main Failure Mechanisms}

The shearing resistance of foundation soil is the main factor affecting the stability of the embankment constructed on soft clay. The geogrid or geotextile layers placed at the bottom of the embankment to resist the shear failure in foundation soil and to prevent the embankment fill from sliding.

The main failure modes for a reinforced embankment on soft clay that should be taken into consideration are as follows [2]:

a) Rotational stability of the embankment [figure 4(a)].

b) Lateral sliding stability of the embankment fill [figure 4(b)].

c) The overall stability of the embankment [figure 4(c)].

Figure (4) shows the main failure modes for a reinforced embankment on soft clay. The failure due to rotational can be deep-seated or shallow. The shallow failure occurs when the soft clay is located at a shallow depth. In case of retaining wall the shallow depth that is, depth less than 1.5 times of the width of the retaining wall base. Deep-seated failure occurs along a cylindrical surface due to the existence of soft clay layer at a depth more than 1.5 times the width of the retaining wall base [3].

The critical cylindrical failure surface can be determined by trial and error and or finite element programs. Also, the designer must consider the ultimate limit states which include: rotational stability of the embankment, lateral sliding stability of the embankment fill, and the overall stability of the embankment to determine the maximum tensile force needed to resist the rotational limit state and lateral sliding, then the number, the length, the spacings of the geogrid layers can be calculated to get a safely reinforced embankment. This safety cannot be achieved without using reinforcement. The stability analysis of the embankment slope can be carried out by various method like Limit Equilibrium Method, Spencer's method, Bishop's method, and finite element programs. 


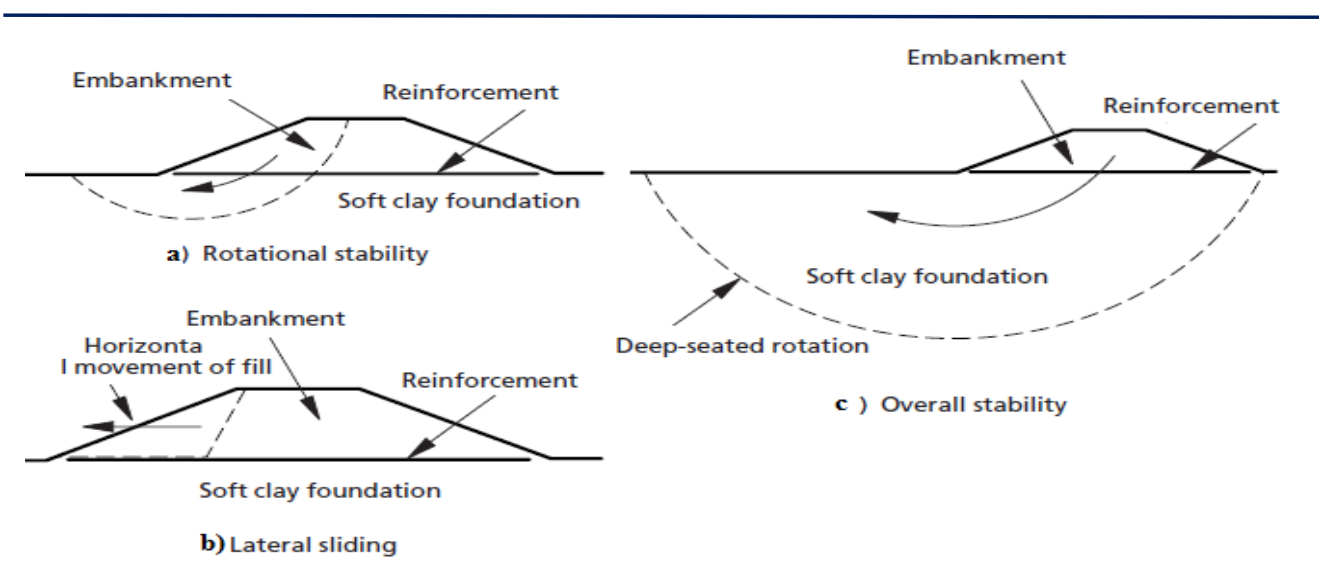

Fig. 4: The main failure modes for the reinforced embankment on soft clay (after BS 8006-1,2010)

\section{Design Method of Reinforced Embankment}

Since 1982 till now, many research papers have been published about the design of reinforced embankment $[4,5,6,7,8,9,10,11,12,13,14]$. Kasim et al. studied the safe height of the reinforced embankment on soft clay with different geotextile spacing [15]. Siavoshnia et al. studied the effect of the number of geotextile layers, the length of geotextile, and geotextile stiffness [16]. Payam Majedi et al. studied the effect of the geogrid Stiffness, the embankment slope, and the number of geogrids layers on reinforced embankment deformation [17]. The common method of construction the reinforcement embankment is laid the geogrid or geotextile horizontally in parallel with the same length. In some cases, the structural designers may take the grid layers with different length. Jewell et al [4] developed a set of charts to design the reinforced embankment. The two-part wedge program WAGGLE used to estimate the value of the maximum horizontal force (T) required to keep the stability of the embankment slope as shown in figure (5).

In this method, the seismic load is not taken into consideration. Internal and external stability failure mechanisms must be evaluated. The design charts to determination reinforcement length according to slope angle $\left(\beta^{\circ}\right)$ are shown in figure (6).

From charts, the minimum length of reinforcement (L) can be determined based on the slope angle $\left(\beta^{\circ}\right)$ and the height of the embankment $(\mathrm{H})$. 


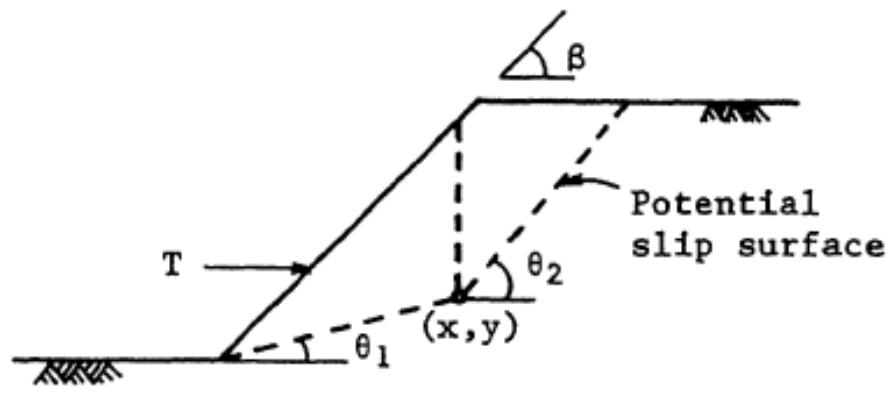

Fig. 5: The two-part wedge mechanism (After Jewell et al,1991)
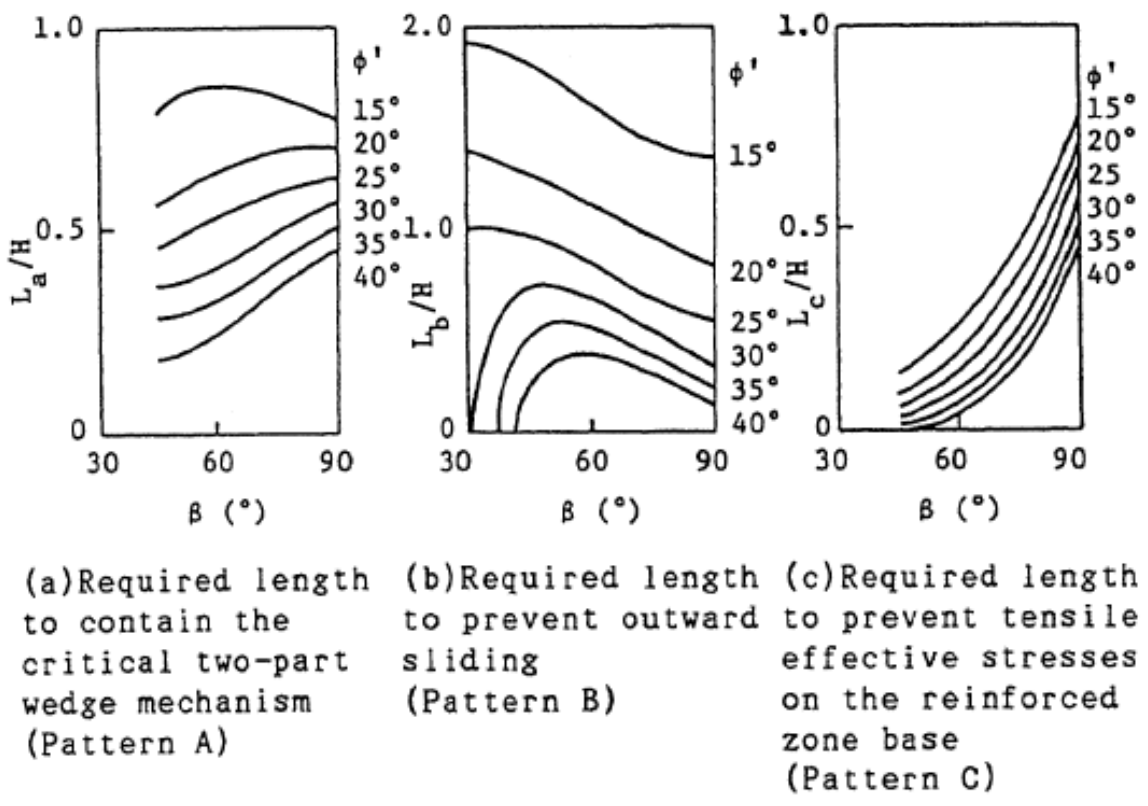

Fig. 6: Determination the reinforcement length (After Jewell et al,1991).

\section{Numerical Analysis}

The steps for analysing using GEO5 program can be summarized as follow:

\subsection{Geometry of Model}

In this analysis, the main model is symmetric with $3 \mathrm{~m}$ height, $10 \mathrm{~m}$ crest width, and with slope $1 \mathrm{~V}: 2 \mathrm{H}$ as shown in figure (7). The traffic load was simulated as a surcharge load equal $10 \mathrm{kN} / \mathrm{m}^{2}$. The depth of clay layer $5 \mathrm{~m}$. 


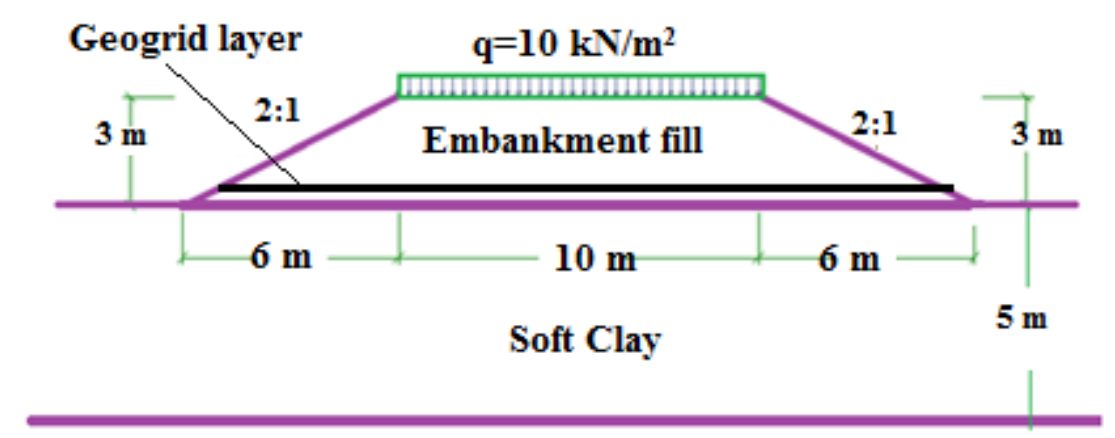

Fig. 7: Geometry of Model

\subsection{Properties of Materials Used in Modelling}

The materials characteristics used in this analysis were as follows:

Embankment fill: sand with a unit weight $=19 \mathrm{kN} / \mathrm{m}^{3}$, cohesion $(\mathrm{c})=0$, friction angle $(\phi)=35$ degrees, modulus of elasticity $(E)=35 \mathrm{Mpa}$, and Poisson's ratio $(v)=0.3$.

Foundation soil: clay with a unit weight $=18 \mathrm{kN} / \mathrm{m}^{3}$, cohesion $(\mathrm{c})=20 \mathrm{kN} / \mathrm{m}^{2}$, friction angle $(\phi)=0$ degree, modulus of elasticity $(\mathrm{E})=10 \mathrm{Mpa}$, and Poisson's ratio $(v)=0.4$.

The reinforcement: a layer of geogrid, the type is Tensar 160RE, the coefficient of direct slip along reinforcement $=0.85$ and the coefficient of the interaction of soil and geo-reinforcement $=0.9$.

\section{Method of Analysis}

The stability analysis of the geogrid reinforced embankment has been done by GEO5 program. GEO5 is a group of programs using to solve most geotechnical problems. GEO5 program contains two options to solve geotechnical problems: traditional methods and finite element method (FEM). The Finite element method gives more details for the behavior of soil and allows the designer to study more variables during the design process. The model parameters are: unit weight $(\gamma)$, modulus of elasticity (E), Poisson's ratio $(v)$, friction angle $(\phi)$ and cohesion (c). GEO5 (FEM)) program and GEO5 slope stability program was used in this analysis. Various types of modelling were carried out. First modelling was to determine the length and the number of geogrid layers. Second, various values of factors effect on the factors of safety of the reinforced embankment are used to set the maximum and minimum value of these factors. These factors include the effect of geogrid Spacing, the 
height of the first geogrid layer, unit weight of embankment fill, and the angle of internal friction.

\section{Results and Discussion}

The results can be summarized as follow:

\subsection{Effect of Geogrid Spacing}

To study the effect of geogrid spacing, five types of reinforced embankments with Tensar $160 \mathrm{RE}$ geogrid and a continuous length from the edge to edge are modelled, a various geogrid spacing was used as follow $(0.25,0.4,0.5,0.6,0.75 \mathrm{~m})$. Factors of safety for both lateral sliding and slope stability were determined as shown in figures $8 \& 9$. When the spacing between geogrid layers was less than $0.5 \mathrm{~m}$, the factor of safety for both lateral sliding and slope stability was 1.22 and 1.2 respectively, that is unacceptable value. When the spacing between geogrid layers was $0.5 \mathrm{~m}$, the factor of safety for both lateral sliding and slope stability was 1.82 and 1.93 respectively, that is an acceptable value. For geogrid spacing more than $0.5 \mathrm{~m}$, the increase in factors of safety was minimal.

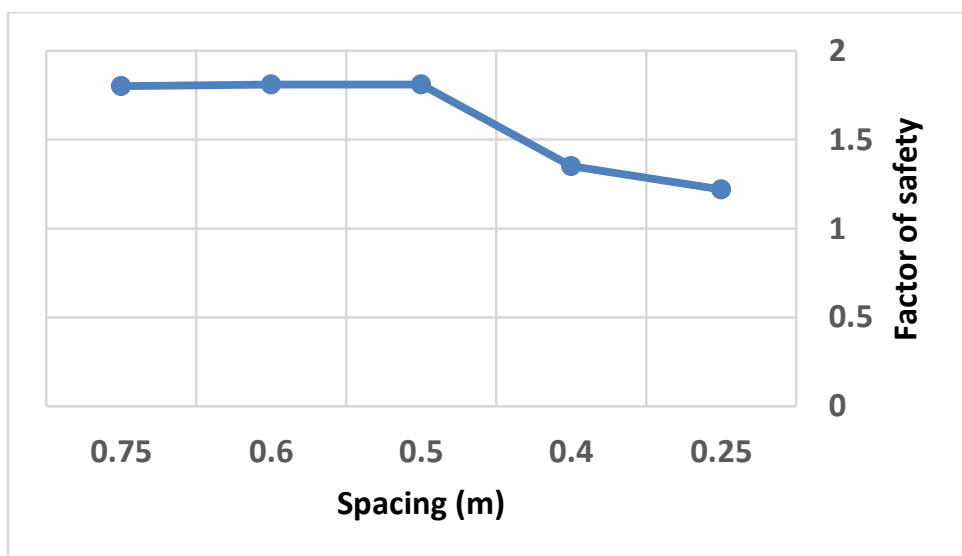

Fig. 8: The relation between geogrid spacing and the factor of safety against lateral sliding 

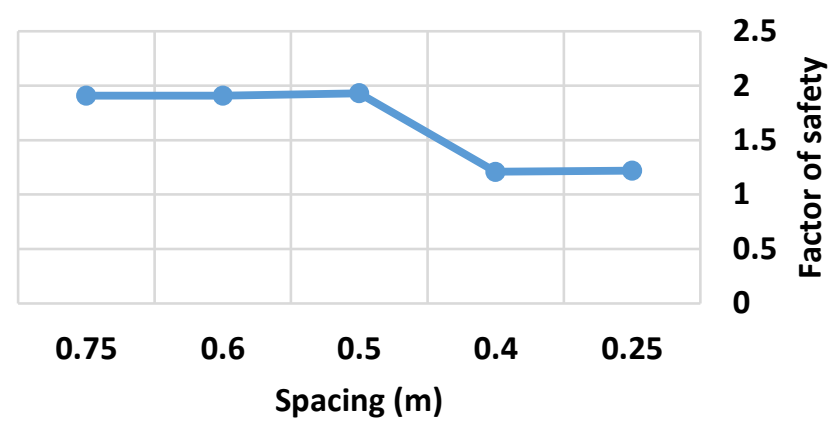

Fig. 9: The relation between geogrid spacing and the factor of safety for slope stability

\subsection{Effect of The Height of The First Geogrid Layer}

The first geogrid layer may be installed at the embankment base, therefore the height of the first geogrid layer equal zero. In some cases, the first geogrid layer may be installed at a distance from the embankment base (see figure 10). To study the effect of the height of the first geogrid, seven types of reinforced embankments with four layers from Tensar $160 \mathrm{RE}$ geogrid and a continuous length from the edge to edge are modelled. The first geogrid layer has various heights $(0,0.2,0.4,0.6,0.8,1,1.2 \mathrm{~m})$ respectively. According to the GEO5 program results, the factors of safety for both lateral sliding and slope stability increased as the height of the first geogrid layer decreased as shown in figure $11 \& 12$.

\subsection{Effect of Angle of Internal Friction}

In this analysis, the reinforced embankment is modelled with different angle of friction for the embankment fill $(30,35,40,45$ degree) respectively.

The results showed that increasing the friction angle for the embankment fill causes to increase the factors of safety for both lateral sliding and slope stability as shown in figures $13 \& 14$. The increase in the angle of internal friction results in increases in the interaction coefficient between the embankment fill and the geogrid layers. Increase the interaction coefficient result in an increase in the frictional resistance of the geogrid layers, and therefore increases the stability of the embankment. 


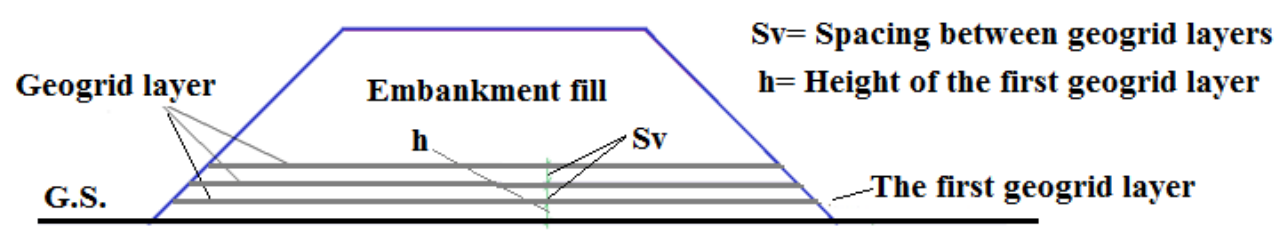

Foundation soil

Fig. 10: Position of geogrid layers

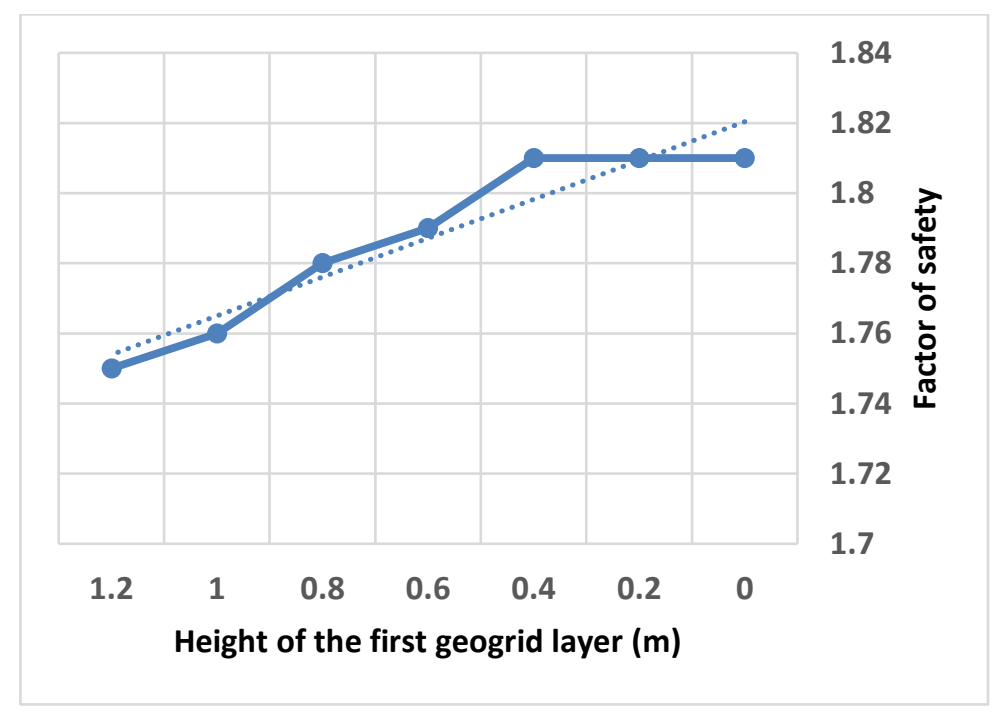

Fig. 11: Effect of the height of the first geogrid layer on the factor of safety against lateral sliding

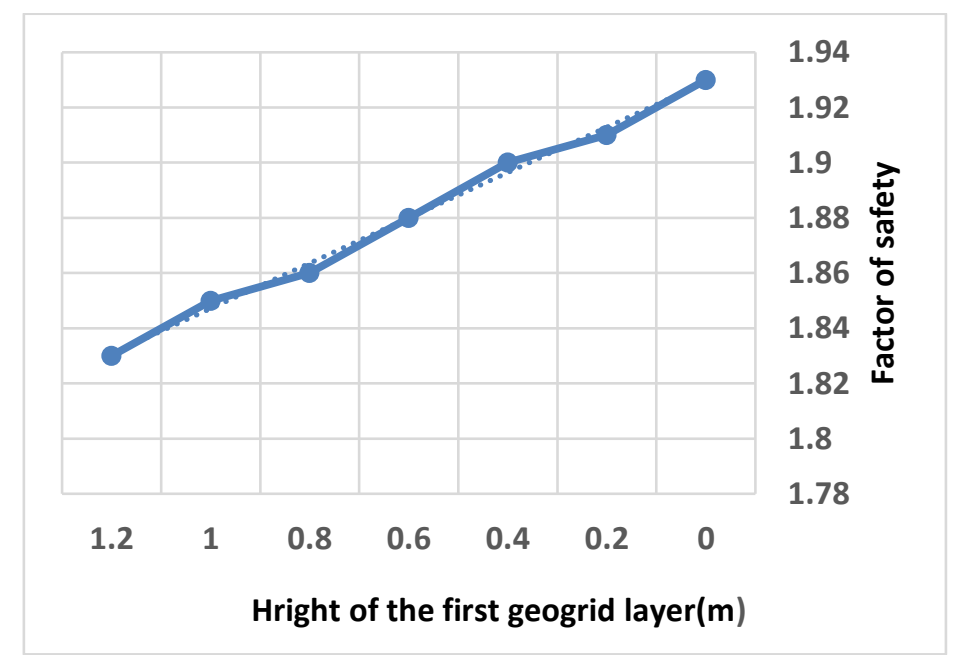

Fig. 12: Effect of the height of the first geogrid layer on and the factor of safety for slope stability 


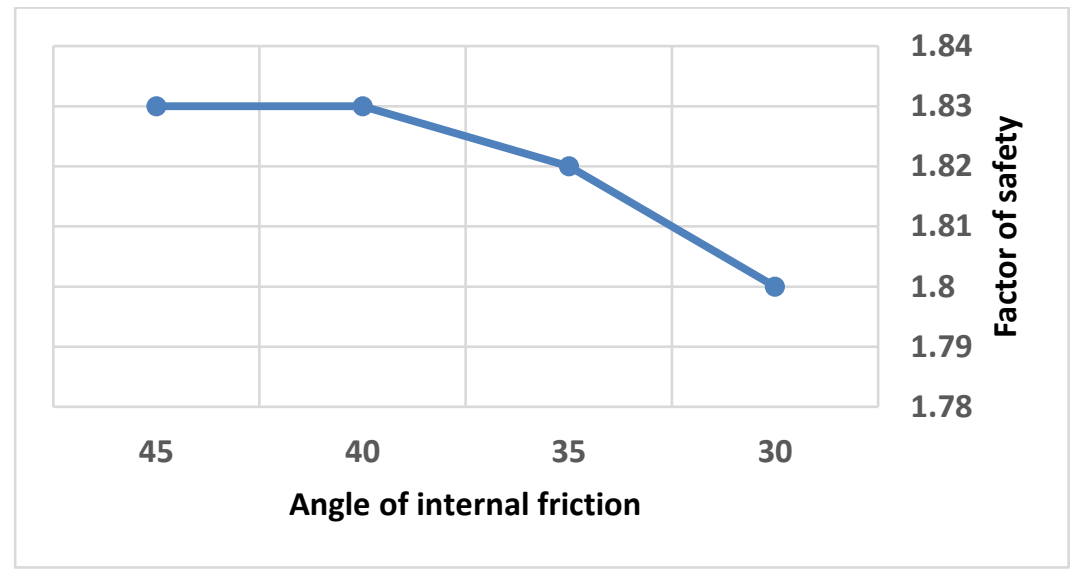

Fig. 13: The relation between the angle of internal friction and the factor of safety against lateral sliding

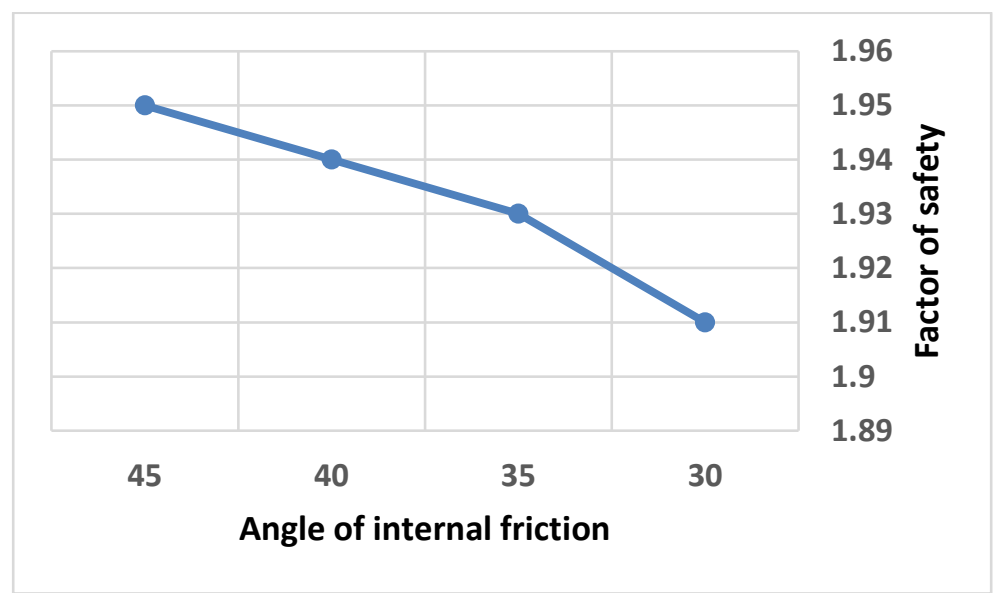

Fig. 14: The relation between the angle of internal friction and the factor of safety for slope stability

\subsection{Effect of Unit Weight}

At this part, the reinforced embankment is modelled with different unit weight for the embankment fill as follow $\left(17,18,19,20,21,22 \mathrm{kN} / \mathrm{m}^{3}\right)$ with the same slope and reinforcement geometry. The results showed that increasing the unit weight for the embankment fill causes to decrease the factors of safety for both lateral sliding and slope stability as shown in figures $15 \& 16$.

The decreasing of the safety factors due to increasing the unit weight of the embankment fill because the increase of the unit weight cause increases the 
active earth pressure which causes lateral sliding and increases the total vertical force which causes increase the total weight of a slice as shown in figure (17).

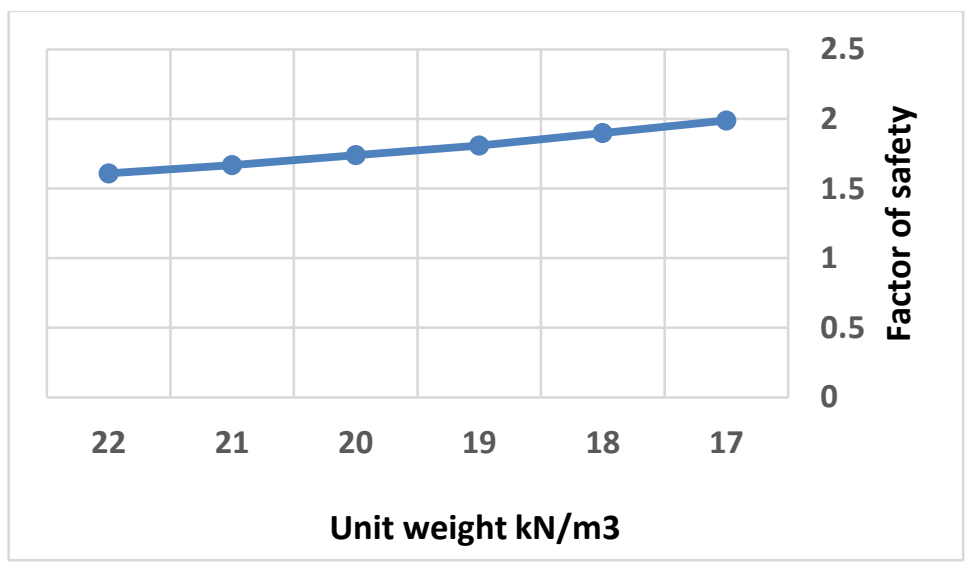

Fig. 15: The relation between the unit weight and the factor of safety against lateral sliding

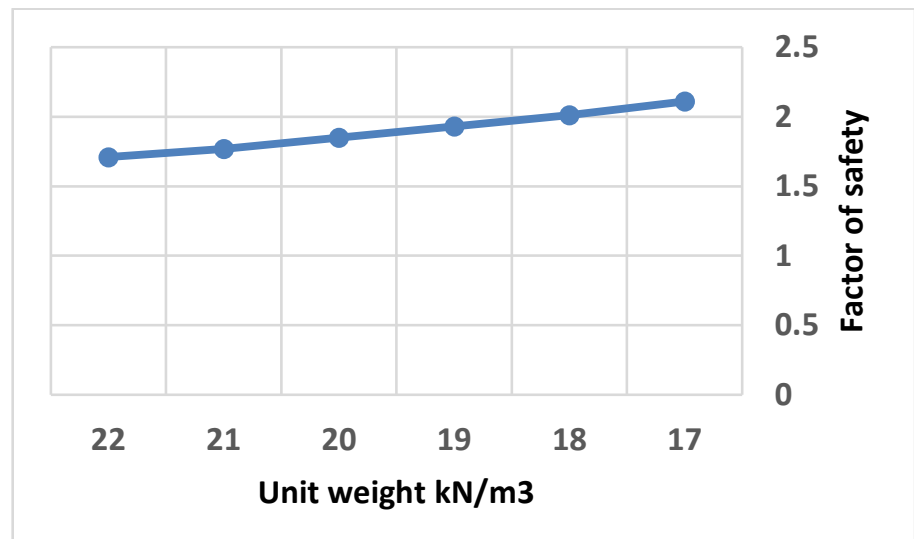

Fig. 16: The relation between the unit weight and the factor of safety for slope stability

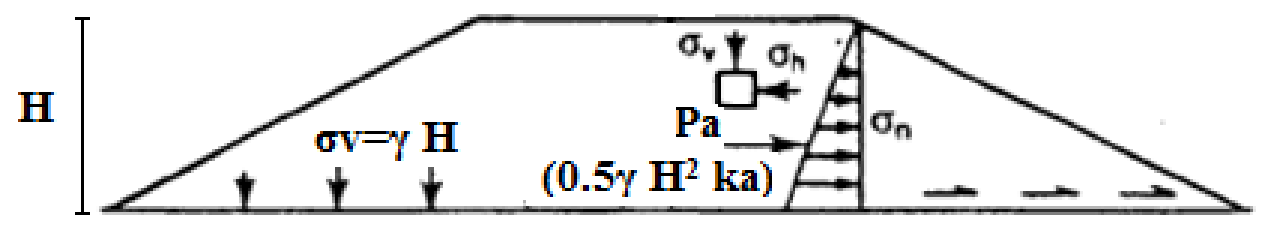

Fig. 17: Effect of the unit weight on embankment stability 


\section{Conclusion and Recommendations}

The main function of the geogrid layers is to provide a stable force at the reinforcement layers-soil interface due to the friction action and the interlock between the soil particles and geogrid layers. So, the reinforcement distributes the applied load over a larger area from the soil and transmit the tensile strength to surrounding soils. The main findings from the analysis are as follows:

1- The optimum spacing between the geogrid layers is $0.5 \mathrm{~m}$.

2- It is recommended installing the first geogrid layer between the embankment base and underlying soft clay layer without any vertical distance.

3- Increasing the angle of internal friction for the embankment fill causes to increase the factors of safety.

4- Increasing the unit weight for the embankment fill decrease the factors of safety for both lateral sliding and slope stability.

\section{References}

[1] 1-The International Geosynthetics Society (IGS), (April,2019). www.geosyntheticssociety.org.

[2] 2-British Standards Institute. BS 8006-1, (2010.) "Code of Practice for Strengthened/Reinforced Soils and other Fills", London: British Standards.

[3] 3-Braja M. Das., (2007) " Principles of Foundation Engineering", $7^{\text {th }}$ ed.

[4] 4-Jewell, R.A., (1991) "Application of Revised Design Charts for Steep Reinforced Slopes", Geotextiles and Geomembranes, Vol.10203- 233.

[5] Ingold, T.S., (1982) "An Analytical Study of Geotextile Reinforced Embankment", 2nd Int. Conf. Geotextiles, Las Vegas, USA, 683-688.

[6] Jones, C.J.F.P., (1984) "Design and Construction Methods. Proc. Symp. Polymer Grid Reinforcement", ICE, London, No.6. 1- 8.

[7] Yamanouchi, T. Fukuda, N. and Ikegami, M., (1986) "Design and Techniques of Steep Reinforced Embankments without Edge Supporting's". Proc. 3rd Int. Conf. Vienna, Geotextiles, Vol.1199-204.

[8] 8-Bonaparte, R. and Schertmann, G.R., (1986) "Seismic Design of Slopes Reinforced with Geogrids and Geotextiles". Proc. 3rd Int. Conf. Geotextiles, Vienna, Vol. 1273-278.

[9] Hirota, Y. and Yamaoka, I., (1986) "Studies on the Slope Stability of Geotextile Reinforced Wall Using Slip Plane Method", Proc. 1st IGS Japan Chapter Symp., Tokyo, 101- 106.

[10] Leshchinsky, D. and E.B. Perry. A., (1987) "Design Procedure for GeotextileReinforced Walls", Geotechnical Fabrics Report, 21-27.

[11] Schmertmann, G. R., Chouery-CUrtis, V.E., Johnson, R.D. and Bonaparte, R., (1987)"Design Charts for Geogrid-Reinforced Soil Slopes", Geosynthetic '87 Conference, New Orleans, USA, 108 -120.

[12] 12-Schneider, H.R. and Holtz, R.D., (1986) "Design of Slopes Reinforced with Geotextiles and Geogrids", Geotextiles and Geomembranes, Vol.329 -51. 
[13] Rowe, K.R. and Li, A.L., (2003) "Insights from Case histories: Reinforced embankments and retaining walls". Keynote Lecture. Landmarks in Earth Reinforcement. Swets \& Zeithlinger, Lisse 803-829.

[14] Blume, K., Alexiew, D. and Glotzl, F., (2006) "The new federal (Autobahn) A26 in Germany with geosynthetic reinforced embankments on soft soils". Proceedings of the 8th International Conference on Geosynthetics, Yokohama, Japan, pp 912-916.

[15] Kasim, F., Marto, A., Othman, B. A., Bakar, I., Othman, M. F., (2013) "Simulation of safe height embankment on soft ground using Plaxis", APCBEE Proceedia 5 152-156.

[16] Siaovashnia, M., Kalantari, F., Shakiba, A., (2010) "Assessment of geotextile reinforced embankment on soft clay soil", the 1st International Applied Geological Congress, Iran 1779-1784.

[17] Payam Majedi, Babak Karimi Ghalehjough, Suat Akbulut, Semet Çelik., (2017) "Effect of Reinforcement on stability and Settlement of Embankment: A Finite Element analysis of Different Kinds of Reinforcing and Construction Conditions", European Journal of Advances in Engineering and Technology, $4(10), 759-764$. 


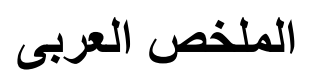

\section{اتزان الجسور المسلحة بالجيوجريد المؤسسة على طين لين}

إن استخدام تقنية تسليح التربة بواسطة الجيوجريد أو الجيوتكستايل يساعد على زيادة استقرار الجسور المؤسسة على التربة الطينية الضعيفة كما يساهم فى انتظام الهبوط

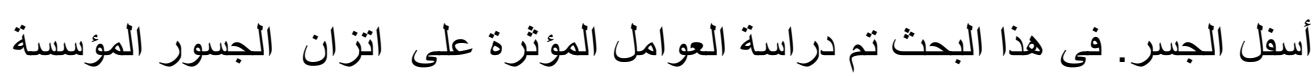
على تربة طينية ضعيفة ومسلحة بطبقات من الجيوجريد وذللك باستخدام برنامج

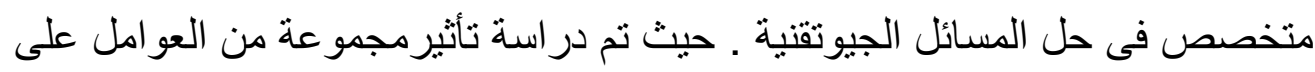
معاملات الأمان للجسر. من ضمن العوامل التى تم در استها العوامل التالية: المسافات الر أسية بين طبقات الجيوجريد , ارتفاع أول طبقة من الجيوجريد , كثافة تربة الردم للجسر, زاوية الاحتكاك الداخلى لتربة الردم للجسر. أظهرت النتائج أن المسافة الر أسية المثلى بين طبقات الجيوجريد هى 0, • متر وأن زيادة زاوية الاحتكاك الداخلى لتربة الردم للجسر تزيد من معاملات الأمان للجسر وأن زيادة كثافة تربة الردم للجسر تقلل من معاملات الأمان للجسر. كما تمت التوصية بأن يتم وضع أول طبقة من طبقات الجيوجريد عند قاع الجسر مباثرة على التربة الضعيفة بدون أى مسافات رأسية. 